\title{
Pneumoconiosis after sericite inhalation
}

\section{E Algranti, A M Handar, P Dumortier, E M C Mendonça, G L Rodrigues, A M A Santos, T Mauad, M Dolhnikoff, P De Vuyst, P H N Saldiva, M A Bussacos}

Occup Environ Med 2005;62:e2 (http://www.occenvmed.com/cgi/content/full/62/3/e2). doi: 10.1136/oem.2003.012609

Background: Between 1997 and 1999 three sericite plant workers in Paraná, Brazil, were diagnosed with pneumoconiosis.

Aims: To investigate and describe the radiological, clinical, and pathological changes in miners and millers exposed to sericite dust with mineralogical characteristics of inhaled dust.

Methods: The working premises were visited to examine the sericite processing and to classify the jobs according to make qualitative evaluation. Respirable dust was collected and the amount of crystalline silica and particle size distribution were measured. Forty four workers were examined by a standard questionnaire for respiratory symptoms, spirometry, and chest $x$ ray. Material from an open lung biopsy was reviewed for histopathological and mineralogical analysis, together with sericite samples from the work site to compare the mineral characteristics in lung lesions and work area.

See end of article for authors' affiliations Results: Respirable dust contained 4.5-10.0\% crystalline silica. Particle size distribution showed a heavy burden of very fine particles (23-55\%) with a mean diameter of $<0.5 \mu \mathrm{m}$. Mean age of sericite miners was 41.0 (11.9) and mean number of years of exposure was 13.5 (10.1). In 52.3\% of workers (23/44), chest radiographs presented a median category of $1 / 0$ or above, and $18.2 \%(8 / 44)$ had a reduced FEV . There was a significant association between exposure indices and $x$ ray category. Histological studies of the lung biopsy showed lesions compatible with mixed dust fibrosis with no silicotic nodules. $x$ Ray diffraction analysis of the lung dust residue and the bulk samples collected from work area showed similar mineralogical characteristics. Muscovite and kaolinite were the major mineral particle inclusions in the lung.

Correspondence to: Dr E Algranti, FUNDACENTRO DMe/ CST, R., Capote Valente 710, 05409-002, São Paulo, Brazil; eduardo@ fundacentro.gov.br

Accepted

3 November 2004

Conclusion: Exposure to fine sericite particles is associated with the development of functional and radiological changes in workers inducing mixed dust lesions, which are distinct histologically from silicosis.
S ericite is a fine grained variety of white mica in the form of silky talc-like plates or needles. It is a secondary muscovite that may be produced by the alteration of feldspar and some other minerals. Sericite is not necessarily chemically different from muscovite although it often may have higher $\mathrm{SiO}_{2}, \mathrm{MgO}$, and $\mathrm{H}_{2} \mathrm{O}$, and lower $\mathrm{K}_{2} \mathrm{O}$ contents. Sericitisation is common in the early stages of hydrothermal alteration of many igneous and metamorphic rocks. ${ }^{1}$ Sericite is the most abundant constituent of slates and it is often associated with kaolinite. ${ }^{2}$ Pure sericite is commercially used as a filler, carrier, and lubricant. Sericite is not referred to as mica because of its peculiar fine grained structure and distinct commercial applications. There are no other epidemiological studies of sericite dust exposure associated with respiratory diseases in the literature.

A controversy in the literature exists as to whether mica induces pneumoconiosis. An extensive review of the experimental and epidemiological papers, and case studies involving mica exposure up to 1985, reported only a few descriptions of pneumoconiosis due to pure mica exposure in humans and inadequate data on the potential for collagen deposition in experimental animals." Other reviews concluded that mica has a relatively low fibrogenic potential. ${ }^{2}$ However, several case reports presented with careful pathological and mineralogical analysis leave little doubt that mica with low quartz content can be associated with the development of disabling forms of pneumoconiosis. ${ }^{4-6}$ Interestingly, sericite was thought to be one of the main causes of lung disease in underground coal workers, and the object of a historical scientific dispute that led to the broadening of acceptance criteria for compensation of disabled coal miners. ${ }^{7}$ Previous cytotoxic studies, with dust collected in British collieries, showed an enhanced cytotoxic effect for the noncoal mineral content of the samples, mainly kaolin and mica. ${ }^{8}$ What makes the issue more complex is the variable concentrations of silica and other minerals commonly present in different exposure situations.

Sericite production in Brazil is restricted to a few small open cast mines and processing sites in the south of the country. It is difficult to estimate country reserves because sericite is computed under the label of pyrophylite or as talc. In the reported mining area, annual production is estimated to be 11000 tons and reserves to be 2600000 tons. ${ }^{*}$ More than $70 \%$ of the sericite production is marketed for use as insecticide filler, whereas $15 \%$ is used for animal meals, $10 \%$ is used for break lining production, and $5 \%$ is used in the rubber industry.

In 1998 a 51 year old male was admitted to the chest clinic. He was a former agricultural worker until 30 years of age; he worked in a limestone quarry for six months and thereafter worked as bagger for 16 years in the sericite plant from 1982 to 1998. He complained of progressive shortness of breath and dry cough, which led him to seek medical attention. Chest $x$ ray examination showed nodular shadows, suggestive for an open lung biopsy (fig 1 ).

The clinical workout was followed by site inspections that investigated working conditions in the plant, characterisation of dust exposures, and investigations of respiratory health in a group of sericite miners and millers. Histopathological investigations, including characterisation of mineral particles present in the lung biopsy from the above case are also reported.

*Data obtained at the Departamento Nacional de Produção Mineral, Ministry of Mines and Energy, Brazil. 


\section{Main messages}

- Exposure to sericite dust can elicit pneumoconiosis of simple and complicated type.

- There is a strong suggestion of a dose-response effect with sericite exposure.

- Tissue reaction to sericite dust is compatible with mixed dust fibrosis.

- Mineralogical analysis can help explain differences in tissue reactions among silicate exposures.

\section{METHODS}

\section{Site visit}

The working premises consisted of an open cast mining area and a mineral treatment unit, $5 \mathrm{~km}$ apart. Between 1999 and 2000 , three site visits were made to investigate the production process and jobs, to determine qualitative assessment of exposures in different jobs, and to collect ambient dust samples.

\section{Dust sampling and analyses}

The sampling strategy for respirable dust and silica were made after a preliminary visit to the plant to evaluate different job exposures. Respirable dust was collected on $37 \mathrm{~mm}$ PVC membrane filters with a pore diameter of $5 \mu \mathrm{m}$ using personal samplers (Bendix BDX 44, Lewisburg, WV, USA) calibrated to a flow rate of $1.7 \mathrm{l} / \mathrm{min}$, with the collecting head placed in the worker's breathing zone. A total of six samples were collected and analysed by gravimetry and $x$ ray diffraction according to well standardised methods. ${ }^{9}{ }^{10}$ For each sampling point, a threshold limit value (TLV) for silica was estimated according to Brazilian legislation. ${ }^{11}$

Bulk samples were collected for mineralogical analysis and comparisons with the mineral residue in lung tissue. Particle size distribution was determined on samples collected in the drying and bagging areas with an IOM inhalable dust sampler (SKC, Eighty Four, PA, USA) placed at head height. Mixed esters of cellulose membrane filters (Millipore, pore size $0.22 \mu \mathrm{m}$ ) were used for optical microscopy and polycarbonate filters for scanning electron microscopy. According to the normalised method BS-3406, ${ }^{12}$ feret horizontal diameter of about 2000 particles was measured by image analysis under optical (magnification $400 \times$ ) and scanning electron microscopy (magnification $1000 \times$ ).

\section{Evaluation of exposure}

There were no routine dust measurements made in the plant. Years of exposure and latency time from the first exposure were used as exposure indices. A qualitative assessment of exposure, derived from site visits with the plant managers and industrial hygiene technicians was developed. It took into account 10 existing jobs that were classified in five groups: heavy, moderate, low, very low, and minimal exposures. Since many years of plant operation major changes in ventilation occurred only in 1998 after pneumoconiosis was diagnosed in three workers.

\section{Subjects}

It was estimated that about 500 workers were hired since the beginning of the plant operation in 1939. Registration of employees was only started in 1943. A listing of 211 workers, currently or previously hired from 1974 to date was the only information available in the plant register. Subjects with less than one year of employment were excluded. This resulted in a total of 110 eligible subjects, of whom 11 were dead. However, irrespective of an exhaustive search we were able to

\section{Policy implications}

- Exposures to sericite dust should be strictly regulated and controlled.

- Sericite workers should be included in occupational hygiene programmes similar to other workers exposed to known fibrogenic dusts.

recruit only 28 current workers (19 from the list and nine hired before 1974) and 26 former workers for this investigation. From this total of 54 subjects with exposure history in the plant, three refused investigations and seven were excluded because of previous known exposure to asbestos in an asbestos-cement plant, leaving a total of 44 subjects for this evaluation.

All the study subjects were fully informed on the investigation methods and procedures and an informed consent was obtained from each subject.

\section{Medical evaluation \\ Questionnaires}

All subjects answered an MRC 1976 respiratory symptoms questionnaire ${ }^{13}$ providing a comprehensive occupational history.

\section{Spirometry}

Spirometry was performed using a Fleisch pneumotacograph (Pulmonary Data Service Inc, Louisville, CO). Predicted values were derived from Brazilian regression equations. ${ }^{14} \mathrm{~A}$ test was considered abnormal when the observed value was less than the lower limit of normality (5th centile).

\section{Chest imaging}

All subjects were submitted to a posteroanterior chest $x$ ray examination, with additional views when needed. Chest radiographs were read by three independent readers (one B reader, one A, and one experienced reader) according to ILO criteria. ${ }^{15}$ Results were summarised as the median reading for profusion of small and large opacities and for the presence and type of pleural thickening.

\section{Lung tissue analysis}

Three patients had undergone lung biopsies for diagnostic purposes (one open lung biopsy and two transbronchial

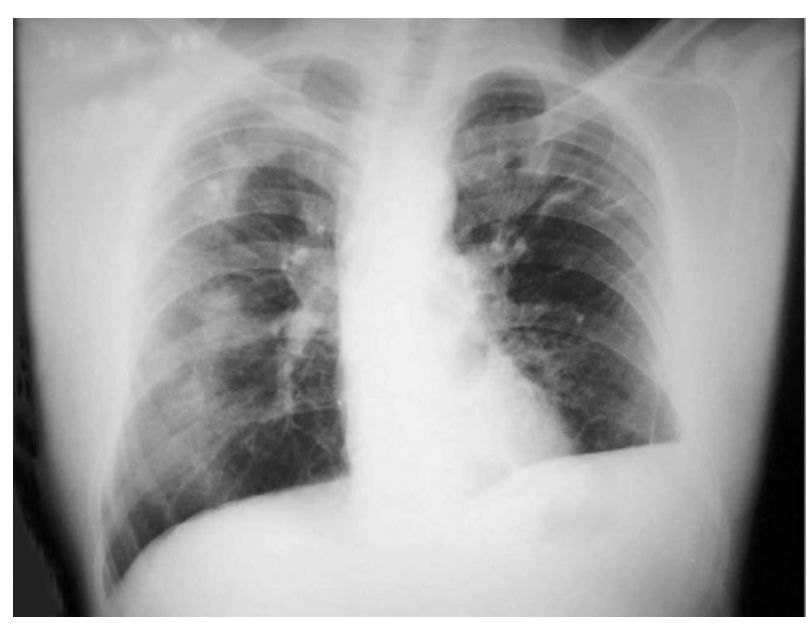

Figure 1 Posteroanterior chest $x$ ray from a 51 year old sericite bagger, after an open lung biopsy. 
biopsies), and a panel of lung pathologists reviewed the slides. Elemental analysis of the mineral particulate inclusions was performed on lung tissues obtained from the open lung biopsy. After the removal of paraffin with xylene, tissue was digested with sodium hypochlorite to remove the organic matter. The total weight of lung tissue processed amounted to $0.07 \mathrm{lg}$ dry tissue. Aliquots of the particle suspension were collected on membrane filters (Millipore, HA type, $0.45 \mu \mathrm{m}$ pore size) and prepared for examination with $x$ ray diffraction $(37 / 40 \mathrm{cc})$ and analytical transmission electron microscopy (TEM) $(1 / 40$ and $2 / 40 \mathrm{cc}) .{ }^{16}$ Elemental analysis of particles was performed by energy dispersive $x$ ray spectrometry (EDS). The EDS detector allowed only detecting elements with $Z \geqslant 11 \mathrm{Na}$. One hundred consecutive individual particles larger than $0.1 \mu \mathrm{m}$ in diameter were examined at $22000 \times$ magnification, sized, and had their chemical composition determined by EDS. All particles present on a known surface area were also counted to determine the particle concentration in number of particles/g dry lung tissue. Global spectra for sericite raw material and lung tissue residue were obtained by analysing the $x$ rays generated while irradiating simultaneously numerous particles with a widely defocused electron beam. It gives information on the mean chemical composition of the samples.

\section{Data analysis}

Data input was made through the EPINFO software. ${ }^{17}$ Data analysis was performed with the SAS statistical software. ${ }^{18}$ Correlations between exposure, spirometric indices, and radiological category were made through analysis of variance (GLM procedure with Scheffe test). A p value of $<0.05$ was considered statistically significant.

\section{RESULTS}

\section{Site visit}

Mine activities were relatively simple. After removing the overburden with bulldozers the ore was easily mined by a front-end loader machine and transferred to trucks. At this stage, the ore was humid and there was very little visible dust. As the ore is mined, high walls are formed, endangering workers and equipment. The trucks transported and unloaded the ore at the treatment unit where it was kept in piles before being fed into the kilns. After drying, the final product was classified by granulometry and bagged. The plant produces fine powdered sericite in different mean particle diameters. Although there were exhaust systems and filters to avoid dust in the environment, they were neither sufficient nor maintained to be considered effective. All operations in the treatment unit were visibly dusty. Jobs were classified in five categories of exposure, but no further analysis on the development of a semi-quantitative index was attempted because of the limited number of dust samples.

\section{Dust sampling and analysis}

In six personal samples collected from workers employed in the drying and bagging areas, crystalline silica content varied between $4.5-10.5 \%$ and respirable dust levels between $0.71-$ $3.4 \mathrm{mg} \cdot \mathrm{m}^{-3}$. Dust levels monitored were above Brazilian TLVs for silica in 5/6 samples.

Optical and scanning electron microscopic investigation of five ambient dust samples collected from drying and bagging areas consistently showed that the airborne particles had a bimodal diameter distribution. Particles equal or smaller than $2 \mu \mathrm{m}$ comprised $57.1-82 \%$ of particle counts, with a large proportion of particles smaller than $0.5 \mu \mathrm{m}(23-55 \%)$.

\section{Medical evaluation}

All 44 subjects were males; among them 21 (47.7\%) had only one job exposure in the sericite plant, whereas $20(45.4 \%)$ had exposures in two different jobs, and three $(6.8 \%)$ had exposures in different three jobs. From the 70 jobs mentioned, 50 were in the dustiest areas (drying, bagging, and carrying). Exposure duration was 13.5 (10.1) (mean (SD)) years, and mean latency of exposure was 19.0 (10.7) years.

The register contained information for all admission and demission dates for subjects hired since 1974. The subjects lost to evaluation had a mean exposure duration of 3.5 (2.9) and mean latency of 14.8 (5.3) years.

Spirometry showed 6 (13.6\%) subjects with reduced FVC, 8 $(18.2 \%)$ with reduced $\mathrm{FEV}_{1}$, and $13(29.5 \%)$ with reduced $\mathrm{FEV}_{1} / \mathrm{FVC} \%$. Table 1 shows anthropometrics, smoking, and spirometric data for the whole group.

Chest $x$ rays from $23(52.3 \%)$ subjects showed median readings of $1 / 0$ or above. Table 2 shows the profusion distribution. Large opacities were present in five subjects (4 B and I C). All large opacities occurred in a background subcategory $2 / 2$ or more. Among the 27 subjects with median readings of $0 / 1$ or above, 14 had rounded opacities only, seven had rounded/irregular, five had irregular/rounded, and one had irregular opacities only. We were unable to show any particular features in the radiological findings associated with different jobs in the plant.

Mean years of exposure for the pneumoconiosis cases were 17.0 (11.0) years and mean latency time 23.0 (10.8). Subjects with median readings of $0 / 0(n=17)$ and $0 / 1(n=4)$ had a similar mean of years of exposure, but the latter had much more latency time, 23.2 (8.0) compared to 12.5 (8.0). This difference was non-significant due to the small number of subjects in the $0 / 1$ group. Five subjects with large opacities had a mean 26.0 (8.1) years of exposure and mean latency period of 28.6 (8.4) years. There was a trend for a doseresponse relation between exposure and major radiological category (fig 2). Analysis of variance of exposure indices means in each major radiological category showed that there was a statistical difference in mean years of exposure between radiological categories 0 and $3(p=0.01)$. Mean $\%$ of predicted $\mathrm{FEV}_{1}, \mathrm{FVC}$, and $\mathrm{FEV}_{1} / \mathrm{FVC} \%$ tended to decline in major category of 3, but analysis of variance within radiological categories were statistically non-significant (fig 2).

\section{Lung tissue analysis}

Histological analyses of the lung tissue revealed altered architecture, due to diffuse areas of irregular interstitial fibrosis, mainly along vessels and airways, resulting in mixed dust fibrotic lesions, macules, and nodules. Few areas of architecturally preserved lung tissue were present. Within the fibrotic tissue there were many dust laden macrophages and foreign body giant cells, containing large number of strongly birrefringent particles. Many foreign body type granulomas were present within the pulmonary interstitium, but no dense whorled collagen bundles were seen. No ferruginous bodies or asbestos fibres were seen (fig 3).

\begin{tabular}{ll}
$\begin{array}{l}\text { Table } 1 \text { Anthropometrics, smoking, and spirometric } \\
\text { data from } 44 \text { sericite workers, Brazil }\end{array}$ \\
\hline Parameter \\
\hline Age (SD) (years) \\
BMl* (SD) \\
Smoking & $41.0(11.9)$ \\
Non-smokers & $25.6(3.6)$ \\
Smokers & 12 \\
Former smokers & 19 \\
Mean spirometric variables (\% predicted) & 13 \\
FVC (SD) & $102.1(16.6)$ \\
FEV (SD) & $94.9(23.2)$ \\
$\mathrm{FEV}_{1} / \mathrm{FVC}$ (SD) & $91.6(12.7)$ \\
\hline
\end{tabular}

*BMI, body mass index. 
Table 2 Distribution of chest $x$ ray median profusion subcategories and large opacities

\begin{tabular}{lll}
\hline Profusion subcategory & $\mathbf{n}$ & Large opacities \\
\hline $0 / 0$ & 17 & \\
$0 / 1$ & 4 & \\
$1 / 0$ & 5 & \\
$1 / 1$ & 4 & \\
$1 / 2$ & 3 & \\
$2 / 1$ & 2 & 2 \\
$2 / 2$ & 4 & 1 \\
$2 / 3$ & 1 & 1 \\
$3 / 2$ & 2 & 1 \\
$3 / 3$ & 2 & \\
\hline
\end{tabular}

Both transbronchial biopsies showed a similar picture consisting of irregular nodular aggregates of macrophages, lymphocytic inflammation, and fibrotic tissue around vessels and airways, forming mixed dust lesions. Macrophages contained large amounts of strongly birrefringent particulate material and anthracotic pigment. No clear granulomatous lesions were seen. There were no dense whorled collagens bundles present in any of the tissues examined.

$x$ Ray diffraction analysis performed on the bulk material and the digested lung tissue residue showed that muscovite, kaolinite, and quartz were the main constituents in both samples. Table 3 shows the chemical composition of the digested lung residue and the dust samples collected from ambient air in the plant.

Data presented in table 4 are the percentage of elements present in the lung tissue digestate showing the mean particle diameters and concentrations of the different particle types present.

\section{DISCUSSION}

Following the identification of three pneumoconiosis sentinel cases, we present an investigation of 44 former and current workers of a small sericite open cast mine and mineral treatment unit in Brazil. This group represents 9\% of the workforce since the beginning of mining activities in 1943. Our results show an unusually high prevalence of pneumoconiosis $(52.3 \%)$. We have further described a relation between sericite exposure, lung function, and $x$ ray category as well as characterised the histological picture of sericite exposed lungs in three workers as a mixed dust pneumoco- niosis type lesion, and the lung dust contents in comparison with the ambient samples collected from the mine.

The subjects that could not be traced had a significantly shorter exposure and latency period, which would certainly result in a lower percentage of pneumoconiosis cases in this industry. However, even in the very unlikely event of all being normal, the pneumoconiosis cases would be over $20 \%$ of the sample.

The objectives of dust sampling were to determine crystalline silica concentration, particle size distributions, and chemical characteristics of the plant exposure hazards. Crystalline silica concentration in the ambient air varied between $4.5-10.5 \%$, and 5/6 of the samples analysed were above the Brazilian TLV for silica. ${ }^{11}$ The Brazilian formula for calculating TLVs for silica is equivalent to the limit of $0.1 \mathrm{mg} \cdot \mathrm{m}^{-3}$. Particle size distribution was bimodal, with particles smaller than $0.5 \mu \mathrm{m}$ in diameter representing $23-55 \%$ of the total particle burden.

Dust exposure from micas appears to be an uncommon cause of pneumoconiosis. ${ }^{2}{ }^{19}$ Experimental and epidemiological reports, and case studies before 1983 were detailed in an excellent literature review. ${ }^{3}$ The authors concluded that mica is "moderately toxic and may induce pneumoconiosis". From the 368 cases of pneumoconiosis associated with mica exposure, only 66 were considered as definite or probable mica pneumoconiosis. ${ }^{3}$ Most of the cases came from mica mining, mineral processing, and other uses, like rubber manufacturing, usually after more than 20 years of exposure. Since 1983 we were able to find four reports of mica pneumoconiosis in the literature. ${ }^{562223}$ From these reports it is clear that pure mica can cause pneumoconiosis, even with short duration of exposures. ${ }^{6}$ The pneumoconiosis cases here described showed a mean of 17 years of exposure and 23 years of latency time. One of the cases had an exposure time as low as 1.4 years.

Clinical and chest radiographic findings in mica pneumoconiosis ranged from pure nodular pneumoconiosis ${ }^{20}$ to severe interstitial fibrosis. ${ }^{5621}$ Half of our cases were classified with a category of $0 / 1$ or more with rounded opacities, with another seven with predominantly rounded opacities. Pleural thickening and calcification are often suspected to be associated with exposure to mica. ${ }^{23-25}$ However, radiological evaluation of the 44 subjects in our study provides no evidence for this association with pleural disease from pure mica exposure. We found only one case with non-calcified pleural plaques among the seven subjects excluded from this study, based on previous occupational exposure to asbestos.
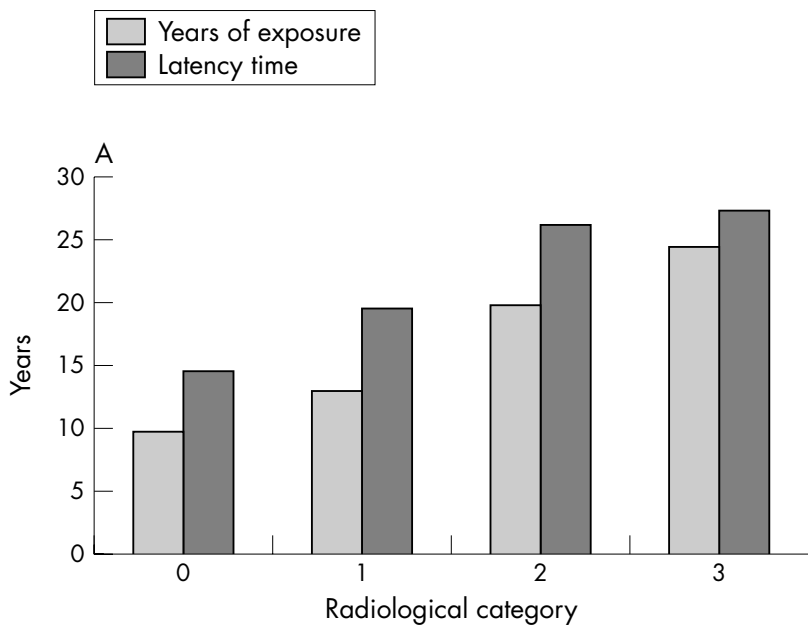
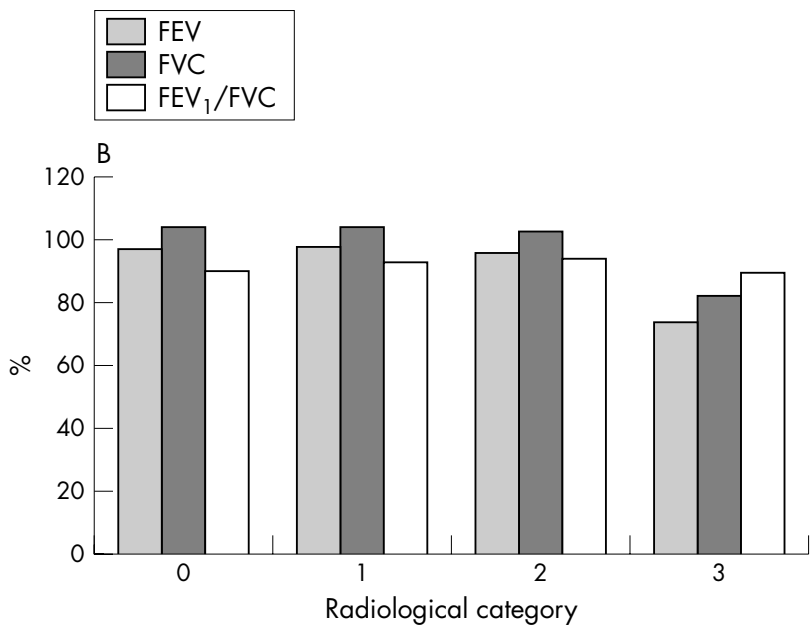

Figure 2 Means of exposure variables and spirometric indices in major radiological categories. (A) Means of years of exposure and latency time in radiological categories. (B) Means of \% FEV,$F V C$, and $F E V_{1} / F V C$ in radiological categories. 


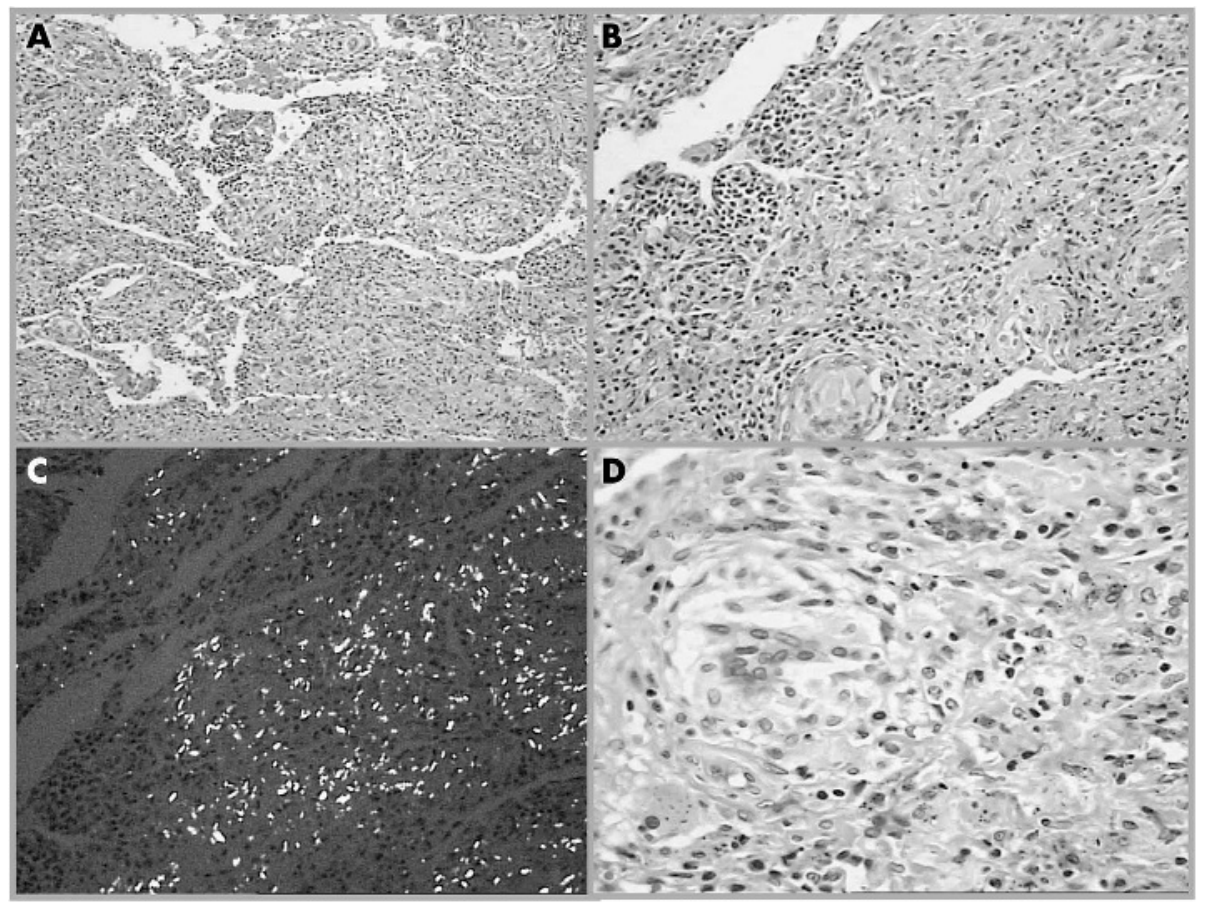

Figure 3 (A) Lung tissue with obliterated architecture showing alveolar septal thickening by interstitial fibrosis with dust laden macrophages and inflammatory cells $(\mathrm{HE} \times 100)$. (B) Peribronchial fibrotic lesion containing collagen fibres, dust laden macrophages, and mononuclear inflammatory cells. Note foreign body type giant cell (bottom) (HE $\times 200)$. (C) Numerous birrefringent particles within peribronchial fibrotic lesion observed under polarised light (HE $\times 200$ polarised light). (D) Granulomatous inflammation with giant cell, collagen fibres, and dust laden macrophages (HE $\times 400)$.

In this study, prevalence of radiological category of $1 / 0$ or above was in $23 / 44(52.3 \%)$ workers. In all these cases, critical investigations of occupational history and latency from first exposure in the plant permitted this diagnosis of pneumoconiosis due to sericite. Such a high prevalence of pneumoconiosis has never been described in Brazil. It is important to note that half of the cases within category 2 or more had large opacities. These cases are possibly due to uncontrolled exposures to dusts in the mineral treatment unit and the large proportion of fine particles in ambient air with sericite dust. Without exception, these 23 subjects worked in the three dustiest areas of the plant-drying, bagging, and carrying.

We were able to analyse lung tissue from three workers, one open lung biopsy, and two transbronchial biopsies. All tissue samples showed histological characteristics compatible with mixed dust fibrosis, with a prominent foreign body granulomas type reaction associated with birefringent sericite particles. Despite the presence of crystalline silica in the dust samples, there were no signs of silicotic lesions. Both cases of transbronchial biopsies had no past history of other confounding exposures. Although we cannot exclude that silicotic lesions may coexist in these patients, it is plausible to assume that a considerable part of the tissue changes could be related to the massive sericite exposure for prolonged periods. Moreover, if silicotic nodules were to be found there was enough latency time for its formation. The histological findings described here are similar to case reports where mica was the unique mineral found in the lungs. ${ }^{45}$ Craighead and colleagues ${ }^{26}$ described the histological findings in the lungs of Vermont slate workers (slate is a metamorphic rock composed of muscovite and quartz), showing lesions of predominantly mixed dust type compatible with phyllosilicate exposure. In contrast, silicotic nodules were common findings in Welsh slate workers. ${ }^{27}$

Although the patient submitted to an open lung biopsy had worked in farming for 18 years prior to the sericite plant work exposure, his lung dust burden and histopathological lesions in the lung biopsies were suggestive of occupational exposure to sericite as the major contributing factor in pneumoconiosis. Exposure to soil dust or to commercially available pesticides can cause particle deposition in human lungs, producing a wide spectrum of tissue reactions. ${ }^{22}{ }^{28}$ It is possible that environmental exposure to soil dust may have contributed to the particle deposits found in the lung residue. However, the predominant dust load was sericite, except for minor differences in aluminium silicates and iron oxides particles. The striking abnormal chest $x$ ray and the histopathological features of mixed dust lesions associated with sericite in lesions are conjunctive evidence for an occupational

Table 3 Elemental composition of the inorganic dust particles from the digested lung residue and the sericite material sample from work site; analytical transmission electron microscopy results

\begin{tabular}{lllllllll}
\hline \multicolumn{7}{c}{ Weight \% of oxides } \\
\cline { 2 - 9 } & $\mathrm{Na}_{2} \mathrm{O}$ & $\mathrm{MgO}$ & $\mathrm{Al}_{2} \mathrm{O} 3$ & $\mathrm{SiO}_{2}$ & $\mathrm{~K}_{2} \mathrm{O}$ & $\mathrm{TiO}_{2}$ & $\mathrm{FeO}$ & Others \\
\hline Lung tissue & 0.6 & 2.2 & 28.5 & 53.8 & 8.7 & 1.1 & 5.2 & 0.0 \\
Raw material & 0.7 & 1.7 & 24.9 & 54.7 & 8.3 & 0.6 & 9.0 & 0.1 \\
\hline
\end{tabular}


Table 4 Particle type, concentration by number \%, and mean diameter in the digested lung residue

\begin{tabular}{lrlc}
\hline Particle type & $\%$ & Mean & Concentration* \\
\hline Crystalline silica & 7 & 2.3 & 596 \\
Kaolinite & 24 & 1.2 & 2043 \\
Muscovite & 51 & 2.2 & 4342 \\
Fe compound & 6 & 0.5 & 511 \\
Ti oxide & 3 & 0.3 & 255 \\
Carbonaceous compounds & 3 & 0.7 & 255 \\
Others & 6 & ND† & 511 \\
All & 100 & 1.7 & 8513 \\
\hline
\end{tabular}

${ }^{*} \times 10^{6}$ particles/g dry lung tissue.

$\dagger N D$, not determined.

exposure and disease development. In an evaluation of 17 subjects from this group who worked in agriculture for periods varying from 2.3 to 28 years, we found no indications of an occupational exposure effect of years in agriculture on profusion of small opacities. In fact, there was a negative association between years in agriculture work and $x$ ray profusion.

In this study, lung tissue analysis showed that particle count far outnumbered mineral particles in the lungs of nonoccupationally exposed humans. ${ }^{16}$ Silicates were associated with simple pneumoconiosis forms in wild living animals environmentally exposed to dust, showing diffuse interstitial infiltration with little collagen deposition in a few cases. ${ }^{29}$ Most of the particles were silicates with a predominance of muscovite. ${ }^{29}$ Slater and Durand ${ }^{30}$ suggested that in coal miners, fibrosis could be explained by the non-coal, nonquartz contents of the mineral dusts. In their experience, most of the analysed particles in the autopsied lungs were silicates, including sericite. Green and Churg ${ }^{31}$ believe that the foreign body type granulomas present in mica associated pneumoconiosis are a distinctive lesion and provide evidence of the specificity of the silicate pneumoconiosis, since they are not usually seen in those exposed purely to asbestos or silica. These authors believe that silicate pneumoconiosis can be diagnosed by pathological techniques. Gibbs and colleagues, ${ }^{32}$ in an investigation of 17 cases diagnosed as "talc pneumoconiosis", showed large variations in mineral contents in the lungs, despite relatively similar histological features among them. In one of the cases, muscovite represented $88 \%$ of the counted particles in the lung tissue.

The digested lung tissue and the raw sericite showed a similar mineral and chemical composition. These results were remarkably similar to those of mica pneumoconiosis published by Davies and Cotton. ${ }^{4}$ Moreover, the particle concentration in the lung tissue was very high. To compare, among 13 cases whose lung tissue were analysed previously with the same methodology, six had concentrations lower than $10^{9}$ particles/g dry lung tissue, six were between 1 and $5 \times 10^{9}$ particles/g dry lung tissue, and only one ex-coal miner had $21 \times 10^{9}$ particles/g dry lung tissue ${ }^{16}$ (see also Dumortier $\mathrm{P}$, unpublished data). A large and detailed database of nonfibrous and fibrous particulates in human lungs from a wide array of exposures is available. ${ }^{33}{ }^{34}$ This report may add useful information to these unique sets of data.

In summary, this current study has shown a high prevalence of pneumoconiosis associated with sericite dust exposure. This particular association of minerals can elicit lung reactions, not commonly seen in silicate dust exposure.

\section{ACKNOWLEDGEMENTS}

The authors would like to thank Prof. A Bernard (Université Libre de Bruxelles, Faculty of Sciences, Geochemistry Laboratory), Dr M Remmelinck (Pathology Department, Hospital Erasme, Brussels), and Dr J Thimpont (Belgian Occupational Diseases Fund and Chest Department, Hospital Erasme) for their skilful help.

\section{Authors' affiliations}

E Algranti, E M C Mendonça, M A Bussacos, Division of Medicine,

FUNDACENTRO, Sao Paulo, Brazil

A M Handar, State Secretary of Health, Paraná, Brazil

P Dumortier, P De Vuyst, Chest Department, CUB Hôpital Erasme, Belgium

G L Rodrigues, A M A Santos, T Mauad, M Dolhnikoff, P H N Saldiva,

Division of Occupational Hygiene, FUNDACENTRO, Pathology

Department, University of São Paulo School of Medicine, São Paulo, Brazil

Competing interests: none declared

\section{REFERENCES}

1 Deer WA, Howie RA, Zussman J. Rock forming minerals, sheet silicates, Volume 3. London: Longman, 1963:11-27.

2 Jones RN, Weill H, Parkes WR. Diseases related to non-asbestos silicates. In: Parkes WR, eds. Occupational lung disorders, 3rd edn. Oxford: ButterworthHeinemann, 1994:536-70.

3 Skulberg KR, Gylseth B, Skaug V, et al. Mica pneumoconiosis-a literature review. Scand J Work Environ Health 1985; 11:65-74.

4 Davies D, Cotton R. Mica pneumoconiosis. Br J Ind Med 1983;40:22-7.

5 Landas SK, Schwartz DA. Mica-associated pulmonary interstitial fibrosis. Am Rev Respir Dis 1991;144:718-21.

6 Zinman C, Richards GA, Murray J, et al. Mica dust as a cause of severe pneumoconiosis. Am J Ind Med 2002;41:139-44.

7 Greenberg M. A battle for compensation for Welsh coal miners: JS Haldane v "Sericite" Jones, 1932-1934. Am J Ind Med 1997;32:309-14.

8 Gormley IP, Collings P, Davis JMG, et al. An investigation into the cytotoxicity of respirable dusts from British collieries. Br J Exp Path 1979;60:526-66.

9 Santos AMA. Determinação gravimétrica de aerodispersóides. Rev Bras Saúde Ocup 1989;17:20-5.

10 Santos AMA. Determinação quantitativa de sílica livre cristalizada por difração de Raios x. Rev Bras Saúde Ocup 1989;17:55-9.

11 Brasil, Ministério do Trabalho. Portaria no. 3214 de 08/06/1978. Norma Regulamentadora No. 15: Atividades e Operações Insalubres, Anexo 12, Poeiras Minerais.

12 BS 3406. Methods for determination of particle size distribution.Part 4: Guide to microscope and image analysis methods. British Standard, 1993.

13 Florey CV, Leeder SR. Methods for cohort studies of chronic airflow limitation, European Series No 12. Copenhagen: WHO Regional Publications, 1982

14 Pereira CAC, Barreto SP, Simões JG, et al. Valores de referência para espirometria em uma amostra da população brasileira adulta. J Pneumol 1992;18:10-22.

15 ILO, International Labour Office. Guidelines for the use of ILO International Classification of Radiographs of Pneumoconiosis, Occupational Safety and Health Series no.22. Geneva: ILO, 1980.

16 Dumortier P, De Vuyst P, Yernault JC. Comparative analysis of inhaled particles contained in human bronchoalveolar lavage fluids, lung parenchyma and lymph nodes. Environ Health Perspect 1994;102(suppl 5):257-9.

17 EPINFO Version 6. Division of Surveillance and Epidemiology. Epidemiology Program Office. Center of Disease Control and Prevention. Atlanta: Epinfo, 1994.

18 SAS Software SAS/STAT. Release 6. 12 Ed. Cary, NC: SAS Institute, 1998.

19 Morgan WKC. Silicates and lung disease. In: Morgan WKC, Seaton A, eds. Occupational lung diseases, 3rd edn. Philadelphia: Saunders, 1995:268-307.

20 Dreessen WC, Dallavalle JM, Edwards TI, et al. Pneumoconiosis among mica and pegmatite workers, Public Health Bulletin. Washington: US Health Services, 1940:250.

21 Pimentel JC, Menezes AP. Pulmonary and hepatic granulomatous disorders due to inhalation of cement and mica dust. Thorax 1978;33:219-27.

22 Gylseth B, Stettler L, Mowe G, et al. A striking deposition of mineral particles in the lungs of a farmer: a case report. Am J Ind Med 1984:6:231-40.

23 Garcia Pachon E, Caliz A, Vidal-Quadras I, et al. Pleural calcifications in pneumoconiosis caused by mica [letter]. Rev Clin Esp 1989;185:45-6.

24 Smith AR. Pleural calcification resulting from exposure to certain dusts. Am J Roentgenol 1952;67:375-82.

25 Kleinfeld M. Pleural calcification as a sign of silicosis. Am J Med Sci 1966;251:215-24.

26 Craighead JE, Emerson RJ, Stanley DE. Slateworkers' pneumoconiosis. Hum Pathol 1992;23:1098-105.

27 Algranti E. Slateworkers' pneumoconiosis. MSc thesis. University of Wales, 1982.

28 Sherwin RP, Barman ML, Abraham JL. Silicate pneumoconiosis of farm workers. Lab Invest 1979:40:576-82.

29 Brambilla C, Abraham J, Brambilla E, et al. Comparative pathology of silicate pneumoconiosis. Am J Pathol 1979;96:149-70. 
30 Slater D, Durrant T. Quartz and pneumoconiosis in coal miners [letter]. Lancet 1982;1:45-6.

31 Green FHY, Churg A. Diseases due to nonasbestos silicates. In Churg A, Green FHY, eds. Pathology of occupational lung disease. New York: IgakuShoin, 1988:177-211.

32 Gibbs AE, Pooley FD, Griffiths DM, et al. Talc pneumoconiosis-a pathologic and mineralogic study. Hum Pathol 1992;23:1344-54.
33 Abraham JL, Burnett BR, Hunt A. Development and use of a pneumoconiosis database of human pulmonary inorganic particulate burden in over 400 lungs. Scanning Microsc 1991;5:95-108.

34 Abraham JL, Hunt A, Burnett BR. Quantification of non-fibrous and fibrous particulates in human lungs: twenty year update on pneumoconiosis database. Ann Occup Hyg 2002;46(suppl 1): 397-401. 